\title{
Quando as revistas eram do ano
}

\author{
Guilherme Filipe
}

Dedicado a Luiz Francisco Rebello

O sonho de um investigador

"Do que fosse a estrutura da primeira revista portuguesa, já que o seu texto não foi editado nem se conservou, sabemos apenas o que a notícia crítica publicada no Espectador de 19 de Janeiro [de 1851] nos diz". (Rebello 1984: 58)

Assim lamentava o autor da História do teatro de revista em Portugala impossibilidade de uma análise mais profunda ao texto original de Lisboa em 1850, uma espécie de ópera-cómica escrita por Francisco Palha e Latino Coelho, visando alguns acontecimentos daquele ano, cujo teor pretendia exercer uma espécie de terapia social - "se ainda temos cura, só o ridículo nos pode curar" -, conforme opinava o articulista da Revolução de setembro (14-011851: 2), sobre o merecimento do novo género popular que se ensaiava. Lisboa em 1850 subiu ao palco do Ginásio Dramático, pelas 7 horas da noite de 11 de Janeiro de 1851, levando a reboque outra ópera-cómica, A Giralda, como se o êxito seguro da obra de Scribe pudesse salvaguardar um possivel desaire para a empresa. Apesar de habituado ao vaudeville, que Émile Doux introduzira muitos anos antes, e à ópera-cómica, pela mão do maestro Miró, naquele sábado, a reacção não foi a desejadamente entusiasta, e o debute da primeira revista do ano pareceu não prenunciar felicidades futuras. Ainda que a crítica do Espectador (19-01-1851: 155-6) pressentisse o talento dos seus autores nos diálogos, não deixava de evidenciar defeitos de contextura, na construção das cenas, na elaboração dos tipos, apenas esboçados, como se aos autores "tivesse faltado a paciência para dar mais alguns traços". A própria representação se ressentira da insegurança dos actores, "pouco certos nos papéis" (Revolução de setembro, 14-01-1851: 2). Quando, no dia seguinte, a revista voltou à cena, o público (parafraseando Pessoa) que a princípio estranhara, acabou por deixar-se entranhar, mantendo-a em cartaz aproximadamente um mês, servindo até como espetáculo carnavalesco desse ano.

Descobrir um documento inédito faz rejubilar qualquer investigador. Luiz Francisco Rebello tê-lo-ia expressado num precioso artigo sobre Lisboa em 1850. Permitam-me, então, este pequeno tributo ao seu labor em prol da História do Teatro em Portugal, dedicando-Ihe este ensaio sobre essa obra de Francisco Palha e Latino Coelho, ocasionalmente descoberta.
Uma caixa de Pandora do teatro

Após aprovação oficial de representação, pela InspecçãoGeral dos Teatros, a 19 de Janeiro de 1851 (L 3, n 311), o manuscrito de Lisboa em 1850 integrou a biblioteca de repertório da sociedade empresária, com o número 131, tratando-se, portanto, da centésima trigésima primeira peça desde a inauguração do Teatro do Ginásio, em 1846, um número apreciável para cinco anos de actividade.

Uma posterior organização acrescentou-Ihe "volume $n^{\circ} 10 "$, correspondendo ao lugar no arquivo definitivo a que se remeteu a obra que entretanto perdera o sentido de actualidade, fenómeno que afecta inexoravelmente 0 género revisteiro, que vive do efémero e que rápido perde o poder actuante, expressão do tempo que o vê nascer, reflectindo o imaginário do auditório a que se destina, e que necessita de continuada actualização, que Ihe prolongue por algum tempo ainda o prazo de validade, a bem do cofre do empresário. E esse tempo, que Ihe esvazia a alma do momento, remete estas obras para o dispensário dos documentos sociológicos, para estudos posteriores sobre crises de mentalidade e de análise historicista. 0 evidente comentário político, agora sem pertinência, necessita ser reinterpretado, fora do tempo em que foi alegoria, e exuberante fantasia, que deslumbrou pelo exotismo da visualidade, do luxo cenográfico e das indumentárias, dos tecidos brilhantes, das melodias sonantes, de tudo o que penetrou os sentidos e viajou directo ao coração do espectador, num apelo lúdico à sensação e à emoção.

Após o incêndio que, em 1921, destruiu o Teatro do Ginásio, o repertório, que se salvou, integrou o espólio bibliográfico do Conservatório Nacional, ao Bairro Alto. Aí ficou resguardado de olhares investigadores, encaixotado, sem referência específica, guardando para sempre as marcas de fogo e de água. Sem tratamento arquivistico, por pouco não sofreu o destino do desaparecimento definitivo...

Valeu-Ihe o gosto por "papéis velhos" de Eugénia Vasques, professora da Escola Superior de Teatro. Naquele dia, um olhar atento evitou nova catástrofe, e o espólio do Ginásio transitou para o limbo das obras que esperam redenção definitiva - se não for pela edição impressa, que seja pelo seu estudo. Entre os manuscritos do Arquivo Histórico da Escola Superior de Teatro e Cinema, três armários de Pandora, muitos inéditos partilham o destino esperançoso de Lisboa em 1850: salvados do incêndio, aguardam o resgate do esquecimento.
Guilherme Filipe é actor, professor de teatro, Mestre em Estudos de Teatro pela Faculdade de Letras de Lisboa, com a dissertação Percursos itinerantes: $A$ companhia de Rafael de oliveira, Artistas Associados. Investigador do Centro de Estudos de Teatro (FLUL), prepara actualmente uma tese de doutoramento a apresentar à mesma Universidade. 


\section{Lisboa em 1850}

Quando se discute tanto a subsistência deste género popular, cuja história se fez de ironia e contestação, e se pretende legitimar o seu estatuto, mais por razões de preservação de postos de trabalho, e menos pela análise crítica do seu conteúdo literário, à distância de século e meio, Lisboa em 1850 surge com o valor de um documento sociológico de interesse. No folhetim da Revolução de Setembro (01-02-1851: 3), Lopes de Mendonça definiua como um "espirituoso e humorístico despropósito em 3 actos [...] caricatura um pouco literária", revelando a falta de "um certo número de personagens indispensáveis", e esperava que "todos [ressuscitassem] com as suas qualidades, para escarmento dos maus e glorificação eterna dos justos". Na realidade, a obra revela a criança que tenteia os primeiros passos, mas onde se nota já um "trabalho sério de sintese, partindo de premissas, e deixando inferir através de massas pitorescas determinadas leis sociológicas - trabalho análogo ao que é em livro o Graindorge, de Taine, e em desenho o Virelocque, de Gavarni" (Almeida 1993: 47). Genealogicamente aparentada com a família farsante, do clã da comédia, o género revisteiro tem por moto o ridendo castigat mores, e por tempo a vivência de um momento histórico, social e espectacular específico. A revista exprime-se pelo exacerbamento do ridículo; pela utilização da facécia burlesca, que cria uma propositada desarticulação com a realidade, engaja a atenção do espectador, confronta-o com a perspectiva retorcida de factos e agentes, reconhecidos a uma distância criteriosamente crítica, e induz-Ihe provocadoramente a catarse do riso. Houve uma "época em que suficiente era a ironia, o apodo, a verve, o comentário para que este excepcional género dramático se impusesse e vencesse!" (Portela 1919: 86), para que se tornasse na "melhor das formas do panfleto [...] falado, aquele em que o escritor, bem em face da turba Ihe avergoa as carnes com o seu látego, dispensando o intermédio da imprensa, que falha sempre nos povos sem hábitos de leitura, e produzindo um instantâneo de persuasão e emoção, mil vezes superior ao das outras arengas críticas, escritas." (Almeida, ibid.)

Lisboa em 1850 delineia já as qualidades intrínsecas definidoras deste género crítico: "premissas seguras e quadros de exposição humorística, escolhidos entre os típicos da vida portuguesa, sob respeito de convergência à comprovação duma tese ou lei geral, enunciada como fecho" (ibid: 48). Surgida no final de um dos períodos controversos da história portuguesa oitocentista, a segunda ascensão e queda do Ministério de Costa Cabral (1849-
1851), poderíamos pensar que Francisco Palha e Latino Coelho iriam patentear uma visão oposicionista sobre o mal-estar que "na rua, nos salões, nos jornais e nas câmaras se erguia". (Bonifácio 2001: 450). Qualquer dos autores partilhava com outros intelectuais a hostilidade ao presidente do Governo, tido como corrupto, concussionário, e procurando abafar os protestos com um projecto de lei de imprensa (01-02-1850), que prostergava os direitos e garantias da liberdade de pensamento, e que ficou conhecida como a "lei das rolhas". Talvez por isso, Lisboa em 1850 prefira ironizar sobre comportamentos, sobre fórmulas passadiças de dramas românticos da escola de Coimbra, ultrapassados pelos novos tempos de óperas-cómicas e de paródias - que Palha motejou em 0 andador das almas (1850), Gomes de Amorim glosou em Figados de tigre (1857) e outros continuaram ad nauseam -, e a nova forma de literatura industrial - o jornalismo e as suas publicações sintetizando a crítica política na apoteose final do $3^{\circ}$ acto em que a Deusa Toleima, sentada no seu trono, saúda o ano de 1850, o "ano de pipinhos", dos que se acham mais do que são, e coroando-o com "um molho de cebolas", ao som de realejos.

0 tom geral da obra é burlesco, sem grande preocupação de continuidade narrativa, ao longo de três actos, habitados por figuras alegóricas, agindo as personagens populares como uma realidade de comparsas mudos. Cada acto enquadra-se num ambiente cenográfico individualizado; três "vistas" sequenciais, de rua (Lisboa), de vinhedos (além Tejo) e de cenário teatral (caverna de Macbeth), correspondendo à progressão cronométrica do último dia do ano. Se as classes laboriosas madrugam em Lisboa (acto I), a burguesia prepara-se para o piquenique literário na outra banda (acto II), e o dia termina na frequência do espectáculo teatral (acto III), numa sociedade que goza um superavit de divertimento, e o Estado um deficit no orçamento. Sinónimo da crise vivida - parecenos -, o sentido da diversão é exacerbado, com referências factuais precisas a diversos acontecimentos e visualidades que se ofereciam ao público lisboeta nesse ano de 1850 Como sucede em outras revistas, na França - que as exportou -, Lisboa em 1850 não apresenta uma partitura expressamente composta, sendo preferida a utilização de música coordenada, entre melodias populares e excertos de obras de repertório erudito. A orquestra do Ginásio tanto executa a música do Profeta, de Meyerbeer, e do Templo de Salomão, de Mendes Leal, como as melodias populares Ó Ana Brites, Maria Cachucha e Ponha aqui o seu pezinho. 


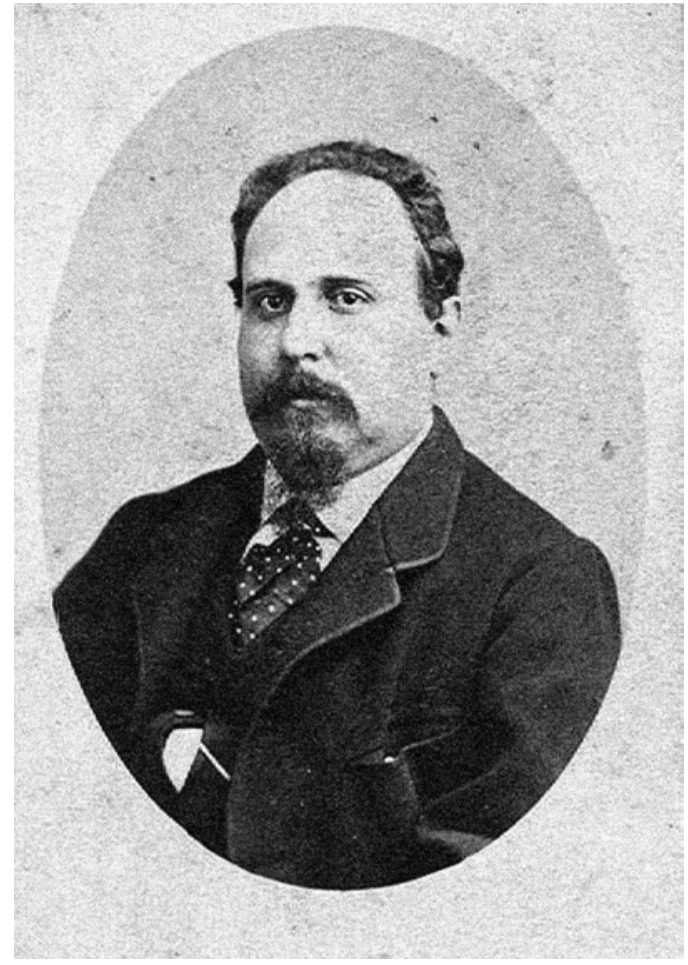

\section{A crítica política de Lisboa em 1850}

\section{Candeeiro de azeite}

Correi sobre estas pedras mal gradadas

Pingas minhas de azeite... ai! Orvalhai-as

Que o pó do Macadam as tem roido!

Candeeiro de gaz

Não sabia que o meu vizinho da esquina fazia versos!

(Palha / Coelho 1851: acto I, cena 1)

Assim principia a obra. Num quadro de rua, dois "Candeeiros" disputam entre si a respectiva importância. Luzes de duas Lisboas distintas - a velha, dos lampiões suspensos, da iluminação pública a azeite (1780), e a nova, da Companhia Lisbonense de Iluminação a Gás (1848) -, são metáfora de um tempo transitório, entre 0 conservadorismo cabralista e o liberalismo de Palmela, em que a aparentemente inócua discussão sobre hábitos fumistas - entre o velho rapé e o moderno cigarro - parece aludir às relações entre o Estado e os "caixas" dos tabacos, e à figura de Farrobo. Com subtileza, a consciência crítica alinha-se com os prenunciados ventos de mudança, que, pouco após a estreia de Lisboa em 1850, se confirmariam no golpe que instaurou a Regeneração, cuja génese terá tido por base a rivalidade entre os "caixas" e o Banco de Portugal (Mónica 1992: 461).

Não admira, pois, que o velho candeeiro - interpretado pelo actor Marques - suspire por um tempo sem "a água sedativa de Raspail, folhetins, traduções terriveis a cinco réis a folha, o Judeu Errante" (Palha / Coelho 1851: acto I, cena 1), ou os ventos franceses das novas ideias republicanizantes. Ambicionava-se uma paz, que pusesse fim ao medo do radicalismo e do povo como força política, que o recém-fundado Eco dos operários exortava, denunciando a exploração dos trabalhadores, das mulheres e das crianças, e a desigualdade social vigente. Não admira que o novo candeeiro - interpretado pelo actor Moniz

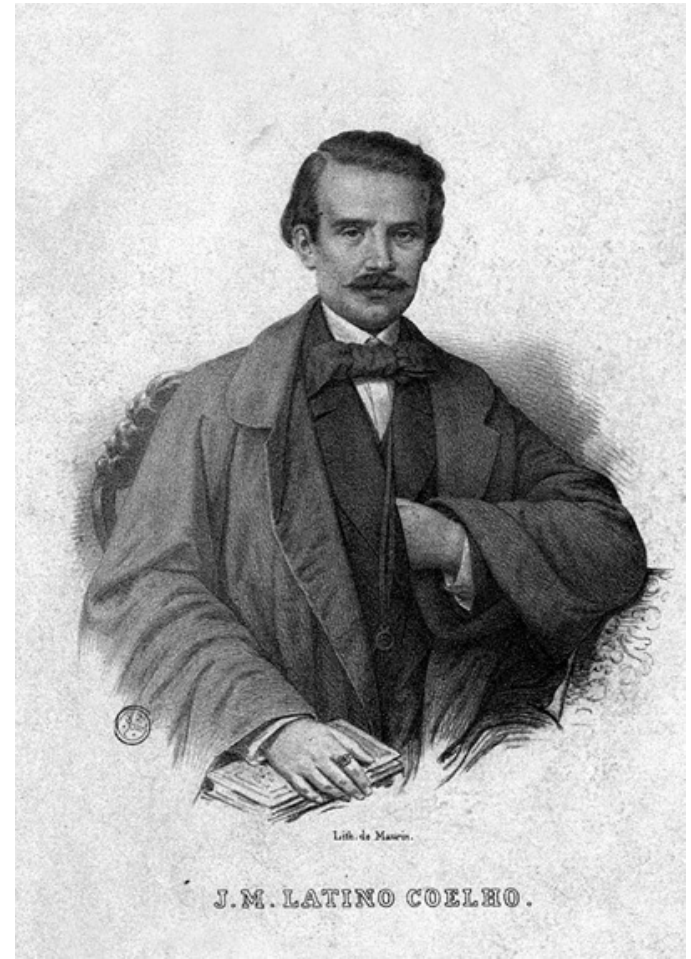

Francisco Palha (1824-1890).

José Maria Latino Coelho em 1856.

(1825-1891)- produto do capitalismo industrial, aluda às renovadas ideias fourieristas - difundidas por Casal Ribeiro em artigos no Atheneu-, do cooperativismo e das associações voluntárias, e sinta o mesmo temor ao idealizar os "falanstérios" iluminados por "bules de chá de limão e os salões com óleo de amêndoa doce" (ibid.). Ironicamente, nem ele mesmo escapará às utopias socializantes no horizonte da modernidade e ao aparecimento da luz electrica.

Os remoques críticos são fortes, mas a evidência política expressa-se em pinceladas ocasionais, sugerindo que a "lei da rolha" pesaria na argumentação dialogal. A figura do "Respeitável Público", personificação do senso comum, da massa anónima que "precisa instruir-se!", a quem todos dão "mel pelos beiços", porque necessário no xadrez político, surge no $2^{\circ}$ acto, na pessoa do actor Pereira, para um piquenique com a "Literatura Portuguesa", a nova cultura literária oitocentista, feita de jornais, revistas, almanaques, e onde sobressai o irreverente "folhetim", em contraponto com um inconsequente "poeta". Metáfora pirandelliana dos espectadores que assistiam a Lisboa em 1850, o "respeitável público", protagonista subtil do espectáculo, a um tempo personagem literária e agente teatral, destinador e destinatário, sofre o assédio de todos os que dele necessitam - "Ó público sensato! Ó público ilustrado! Ó grande e respeitável público!" -, não lhe valendo sequer a força de sua filha D. Pateada, na pessoa da actriz Emília Cândida. Tão pouco escapará, no $3^{\circ}$ acto, colocado no espaço do teatro - numa "caverna como a do Macbeth" -, à perseguição fantasmagórica das óperascómicas, então em voga. Filho de Euterpe, o "respeitável público" sofria de "monomania musical" (Cascão 1998: 445). Tanto será convidado a frequentar "D. Filarmónica" - alusão clara à tradicional Academia Filarmónica -, para escutar um concerto de violino, como o "Baile Nacional" - o moderno café-concerto -, para se deliciar com os requebros voluptuosos das "cancanistas". Dois mundos sociais que 0 aliciam: 


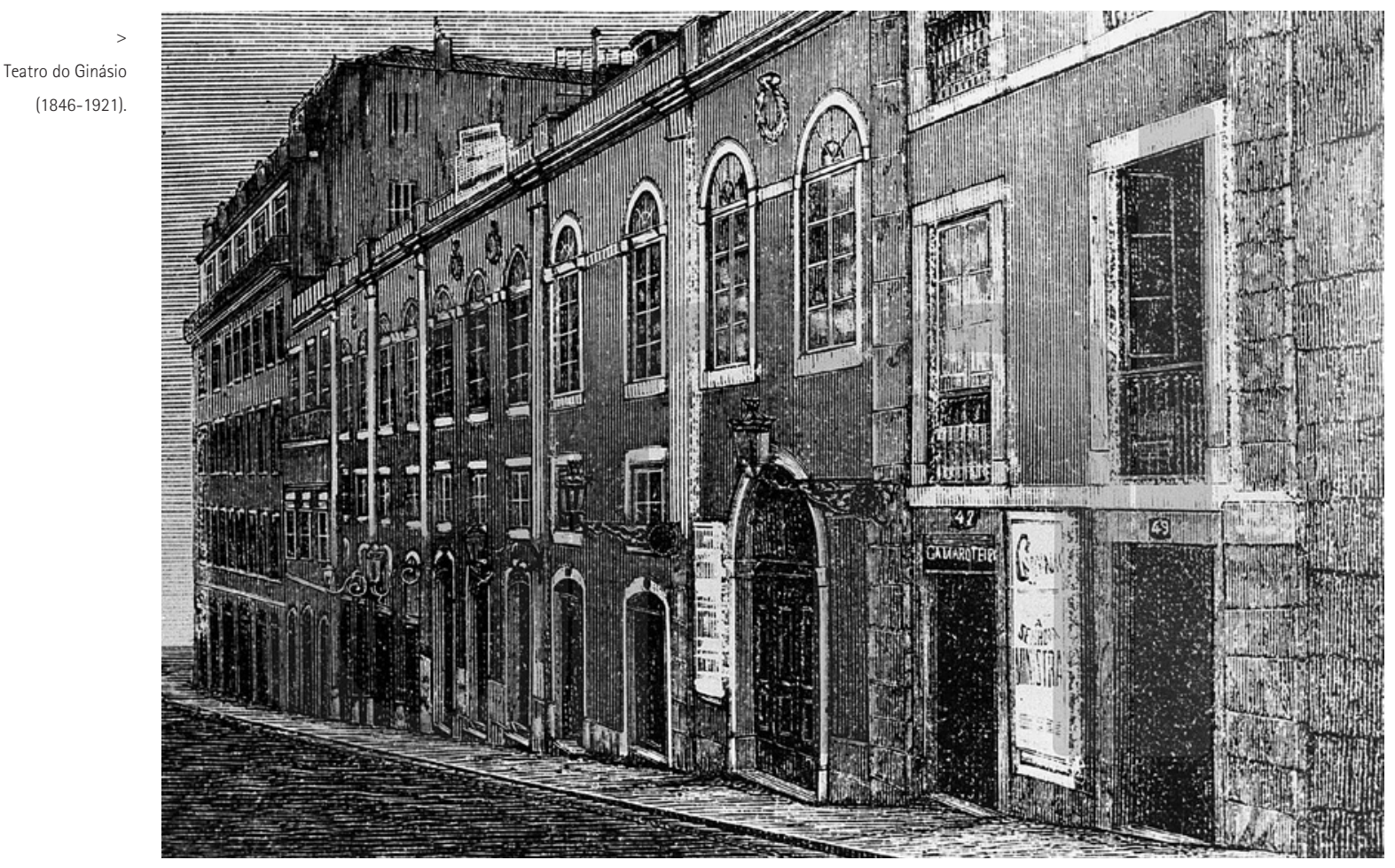

\section{Baile Nacional}

Sim, Sra D. Filarmónica, para ir a sua casa ha-de um pobre homem calçar o sapatinho de polimento, vestir a casaca nova, comprar a luva branca, alugar a traquitana do semi-circulo, estudar finesas para dizer às Senhoras, e eu recebo o Janota de quinzena branca, e luva cor de mel, deixo-o andar pelos meus salões de chapeu na cabeça, à vontade, como se estivesse na estrebaria dos seus péssimos cavalos. [... Eu sou o único verdadeiro comunista de Portugal, ninguém por ora compreendeu aqui a Liberdade, Igualdade e Fraternidade como eu a compreendi! (Palha/ Coelho 1851: acto III, cena 1)

Realidade e ficção na crítica teatral Curiosamente, Lisboa em 1850 sugere a forma de uma partitura em três andamentos, explorando dois temas dominantes: Teatro e Imprensa. No $1 .{ }^{\circ}$ acto, após a breve introdução - cena dos candeeiros -, expõe-se o primeiro tema, desenvolvido no $3 .^{\circ}$ acto, seguido pelo segundo tema, explorado no $2 .^{\circ}$ acto.

Quando a crítica política poderia aprofundar-se, o diálogo dos "candeeiros" é interrompido por um esbaforido "Templo de Salomão", fugindo à perseguição de um "Teatro do Rossio". Aquele recusa voltar à cena do Normal, e este rejeita perder a ambicionada fonte de rendimento. A paródia visa a política cultural do Teatro de D. Maria, mas, sobretudo, levanta a questão do valor de um Teatro Nacional, de um corpus dramático de qualidade literária, em contraponto com os espectáculos de grande aparato visual popularmente apelativos.

Em três anos de exploração teatral, o Normal não correspondia às expectativas do primeiro palco de declamação. Nomeado o Conde de Farrobo para inspectorgeral dos Teatros, acreditou-se que o seu prestígio e bom gosto fossem suficientes para inverter os acontecimentos, e que a estreia do Templo de Salomão, "melodrama sacro de grande espectáculo", de Mendes Leal, trouxesse algum lustro ao Teatro do Rossio. A sociedade exploradora envidou todos os esforços. Epifânio dirigiu a montagem e João
Anastácio Rosa o guarda-roupa, e, não se poupando a esforços, a cena deslumbrou com muitos comparsas, com cavalos - como acontecera no Alcaide de Faro - e, novidade das novidades, com dois camelos. A crítica não se deixou comover por semelhantes visualidades, mas o público opinou diversamente, e encheu o teatro para ver os bailados de Marsigliani, os coristas dirigidos pelo "cabo" José Maria Saloio, as tramóias do mestre Coelho e, sobretudo, os camelos. "Vamos ao Rossio ver os camelos", dizia-se à boca cheia. A 31 de Julho de 1849, deu-se o delírio popular. Nesse ano, o Templo deu um total de 45 representações, prolongando-se ainda no ano seguinte. Disso dá conta Lisboa em 1850:

\section{Templo}

Estranhas caras - ignoradas gentes,

Velhas marrafas vi; vi indecentes

Chapeus da fundação da monarquia,

Gordas sobrinhas que pregara a Tia

Nos longos aguçados, feros dentes

De enormes tartarugas - vulgo pentes!

Vi os verdes carrões, que transportaram

À pia do baptismo os ascendentes

De trinta gerações que já passaram,

Acordarem do sono, e a compasso,

Roda aqui, roda além, marcando passo

Parar à minha porta, e do seu seio

Despejarem patrões, amas, meninos,

Uns grandes... outros pequeninos!

E dum carrão desceram os inquilinos

Dum prédio inteiro... uns gordos, outros finos

E atrás deles depois... o prédio veio!

(ibid: acto I, cena 2)

0 êxito da peça transformava o sentido do Normal, adiando-se a regeneração da cena portuguesa, porque o público preferia os camelos (Sequeira 1955: 158). Em 1850, 
a programação não atraiu os espectadores, excepto aos domingos, quando se exibia o Templo de Salomão, agora sem camelos, devido a cortes orçamentais - insuportável sofrimento, sobretudo para o "Templo"!

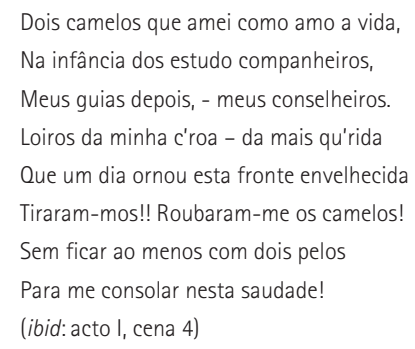

A campanha contra a política cultural da Sociedade Artistica agudizou-se na imprensa: criticaram-se as visualidades, "cosmoramas de fantasmagorias" (Sequeira 1955: 160), próprias do Teatro do Salitre, mas não em D. Maria, onde o teatro deveria ser um prazer intelectual. Só que o público insistia:

\section{Teatro do Rossio}

[...] (tirando um papel do bolso) Eis aqui uma petição com mil assinaturas em que a Lourinhã pede para fazer os seus cumprimentos à Rainha do Sabá.

\section{Templo}

Pois que esperem pelo caminho-de-ferro de Lisboa à Lourinhã, que eu prometo levar-Ihe lá a Rainha do Sabá!

(ibid: acto I, cena 5)

Eis a ironia óbvia às infrutiferas tentativas de criação do caminho-de-ferro, desde 1844 - obras de Santa Engrácia! -, que começarão em 1851 e culminarão na pompa inaugural do troço até ao Carregado, em 1856.

No Teatro D. Maria, para aliviar a animosidade patente, a Sociedade Artística promovera obras de melhoramento - instalara a iluminação a gás - e prometera a representação de Frei Luís de Sousa, que, por fim, subiu à cena, após várias vicissitudes. Aos autores de Lisboa em 1850 não podia escapar o facto; a didascália alude ao tom de representação - a imitação da actriz Josefa Soller e do actor Assis - e reproduz o clima do final do $1^{\circ}$ acto do drama, cujas frases se decalcam:

Templo (imitando D. Madalena do Frei Luis de Sousa)

Mas sem os meus camelos não! Tu não sabes a violência, o terror

com que eu penso em ter de entrar em tua casa, e não encontrar ali

os meus camelos! Parece que vem sobre mim todas as pateadas do mundo! Se fossemos para outra parte, para a rua dos Condes, para o Salitre, para Santo Amaro, mas para ali não...oh! não! Teatro do Rossio (imitando Manuel de Sousa Coutinho) Em verdade nunca te vi assim! Assim, Templo de Salomão! Restanos ainda a escada para o céu, resta-nos aquele anjo mexeriqueiro que mete o nariz em toda a parte, cantando quadras para adormecer crianças ou deitando loas para divertir o povo, e sobretudo (com muito entusiasmo) uma mãe que não mata seu filho, mas morre por elle! (ibid: acto I, cena 5)

Nem o sucesso do drama garrettiano, que os "candeeiros" aplaudem "entusiasmados", impedirá que o "Templo" regresse ao "Theatro do Rocio", nem a entrada do "Limpa candeeiros" - alusão clara à obra de estreia de Ernesto Biester, e ao naturalismo do drama de actualidade:

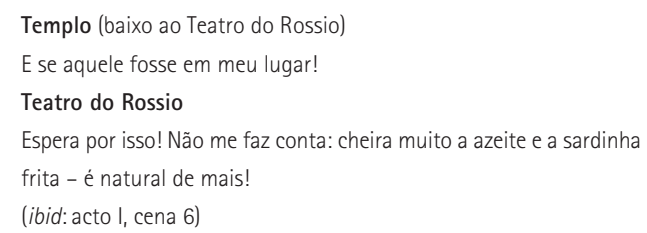

"Anuncia-se ao Respeitável Público que vai chegar a Literatura Portuguesa"

0 tema da imprensa escrita inscreve-se primeiro como uma "ilustração" caricatural, espécie de finura plumitiva bordaliana, cuja abordagem ocorre apenas no segundo acto. A meio do primeiro, "começam as delícias da madrugada", a orquestra "executa o coro das campainhas do Profeta", e a comparsaria invade a cena, numa buliçosa pantomima de ofícios e afazeres:

Um homem abre uma porta, olha para o céu e espreguiça-se; depois vai dentro, traz o barril do lixo que põe à porta. Dois dos das carroças chegam acompanhando sempre a orquestra com as campainhas e levam o barril; ao mesmo tempo começam a passar saloias com ceus burrinhos, homens apregoando leite. Concluido o coro, aparece um homem a uma esquina e ali se conserva algum tempo; saiem dois janotas, e um jovem poeta que vão para o banho. Continua durante esta cena a passar gente.

(ibid: acto I, cena 8)

Revela-se ao espectador uma "vista de rua", com várias casas, entre as quais uma "que tem por cima uma taboleta onde se lê - Livreiro". A esta porta, Braz Tizana - um jovem jornal do Porto -, acompanhado por Monsieur de Calembourg - a leviana inteligência espirituosa e cosmopolita -, "bate duas vezes e ninguém lhe responde". 


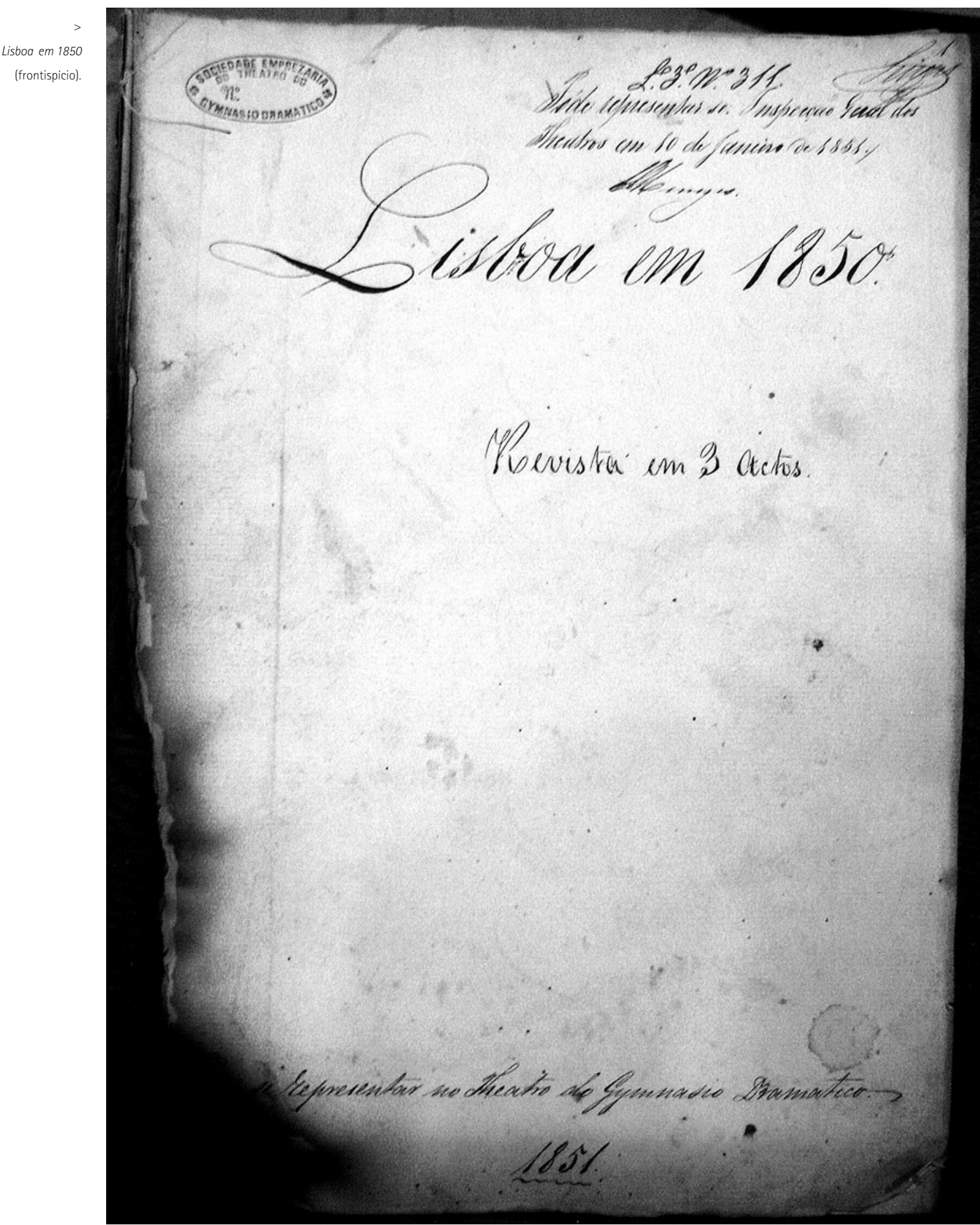

0 breve apontamento humorístico parece aludir ao estabelecimento que António Maria Pereira inaugurara em 1847, "que de livraria começou por ter a tabuleta", e que, segundo J. César Machado, seria "um bazar, um museu, um atelier de pintura, tudo, menos uma loja de livros!" (Rodrigues 1999: 20), num país ainda sem grande hábito de leitura.

Braz Tizana desce à capital em visita de cortesia a D Bibiana da Revista Universal. 0 recém-fundado periódico portuense presta homenagem ao Jornal dos Interesses Físicos, Morais e Literários, fundado em 1841, onde Castilho pontificara, e Mendes Leal, L. A. Palmeirim, Gomes de
Amorim ou A. A. Teixeira de Vasconcelos colaboraram entre muitos. Porém, Braz Tizana é mais do que o jornal de província: é a figura do forasteiro que desce à capital para disfrutar do cosmopolitismo lisbonense, numa atitude de distanciamento crítico; um proto Zé Povinho, como tantos que povoam as cenas-cómicas que fizeram a delícia dos espectadores na interpretação de Taborda, que Camilo retratou no Morgado de Fafe, e Bordalo desenhou no António Maria. A personagem da Revista Universa apresenta, então, o periódico regional à "literatura do país que chega em massa". A cena enche-se dos principais jornais e revistas do momento, como o Atheneo, de Oliveira 
Marreca, dedicado a assuntos literários e científicos, que se pretendia alheio a questões políticas; a Revista popular, semanário ilustrado de Fradesso da Silveira e Latino Coelho, versando temas de literatura, ciência e indústria; ou $A$ semana, jornal literário e instrutivo, fundado por João Lemos e Silva Bruschy, entre outros. Por momentos, é como se a memória do programa da Revista universal (1841) subisse à cena - "os livros eram a muita ciência para poucos homens, os jornais são um pouco de ciência para muitos homens". Lisboa em 1850 faz o elogio da imprensa - o "grande apóstolo do século", para Antero, e a "grande instituição moderna", para Eça -, que a figura do "Grátis" anuncia como "a Literatura Portuguesa" (Palha / Coelho 1851: acto II, cena 3).

Ela serve na educação do "Respeitável Público", com quem confraterniza, no $2^{\circ}$ acto, num satírico piquenique literário, por entre vinhedos de além-Tejo, que caricatura o pretensiosismo dos salões de divulgação de poetas namoradores de revistas literárias, em paroxismos ultraromânticos:

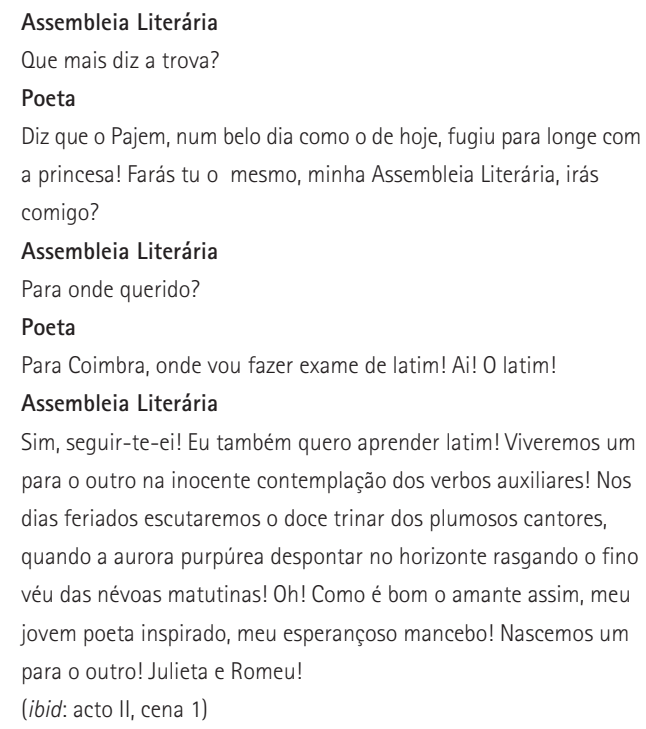

Assembleia Literária

Que mais diz a trova?

Poeta

Diz que o Pajem, num belo dia como o de hoje, fugiu para longe com

a princesa! Farás tu o mesmo, minha Assembleia Literária, irás

comigo?

Assembleia Literária

Para onde querido?

Poeta

Para Coimbra, onde vou fazer exame de latim! Ai! 0 latim!

Assembleia Literária

Sim, seguir-te-ei! Eu também quero aprender latim! Viveremos um para o outro na inocente contemplação dos verbos auxiliares! Nos dias feriados escutaremos o doce trinar dos plumosos cantores,

quando a aurora purpúrea despontar no horizonte rasgando o fino véu das névoas matutinas! Oh! Como é bom o amante assim, meu jovem poeta inspirado, meu esperançoso mancebo! Nascemos um para o outro! Julieta e Romeu!

(ibid: acto II, cena 1)

Possivel alusão a Júlio César Machado, que se estreara na Assembleia literória, em 1849, com apenas 14 anos, com o poema 0 mar, e para a qual traduzira o Cura, de Lamartine? Um século depois, perdem-se as referências óbvias, mas do conjunto da obra guarda-se uma ideia de elogio, que Francisco Palha e Latino Coelho tecem a uma sociedade de literatos em quem se confiava para levar por diante a transformação do país e a Regeneração. Por detrás das figuras representativas dos periódicos em palco subentendiam-se os nomes já citados, mas também os de Rebelo da Silva, Andrade Corvo, João Crisóstomo, Casal Ribeiro, Serpa Pimentel, Camilo Castelo Branco, entre muitos outros, bem como a ideologia vigente. Curiosamente, aquilo que hoje se nos apresenta apenas como objecto de estudo, apesar de ter tido uma recepção cautelosa, falou então à boca cheia às consciências do auditório, num palco feito tribuna política, fórum de ideologias.

\section{Referências bibliográficas}

ALMEIDA, Fialho de (1993), "Estado do teatro. As revistas", Actores e autores (Impressões de teatro), Lisboa, Circulo de Leitores, Obras completas de Fialho de Almeida.

BONIFÁCIO, M. Fátima (2001), "O liberalismo", in Memória de Portugal. 0 milénio português. (coord. geral de Roberto Carneiro), Lisboa, Circulo de Leitores, pp. 424-479.

CASCÃO, Rui (1998), "Vida quotidiana e sociabilidade", in História de Portugal, 0 Liberalismo (1807-1890) (dir. José Mattoso), Lisboa Editorial Estampa, pp. 439-477.

MENDONÇA, Henrique Lopes de (1851), "Folhetim: Revista de Lisboa", in Revolução de Setembro, n² 2638, 1 de Fevereiro, pp. 1-3.

PALHA, Francisco / COELHO, Latino (1851), Lisboa em 1850. Revista em 3 actos. (ESTC, ms.)

PORTELA, Severo (1919), "Postal do autor de uma "revista"", in Almanach dos palcos e salas para 1920. Lisboa: Editor - Arnaldo Bordalo, p. 86. REBELLO, Luiz Francisco (1984), História do teatro de revista em Portugal - I. Lisboa, D. Quixote

RODRIGUES, Ernesto (1998), Mágico folhetim. Literatura e jornalismo em Portugal, Lisboa: Editorial Notícias.

-- (1999), Cultura literária oitocentista, Lisboa, Lello Editores.

SEQUEIRA, Matos (1955). História do Teatro Nacional D. Maria II. Lisboa, [s.n.]. Publicação comemorativa do centenário 1846-1956.

-- (1967). 0 Carmo e a Trindade, Lisboa, Câmara Municipal de Lisboa, $2^{\text {a }}$ edição. Vol. 3 